\title{
ГИДРОЛОГО-ГИДРОХИМИЧЕСКАЯ СИТУАЦИЯ И СОСТОЯНИЕ МЕРОПЛАНКТОНА НА ВЗМОРЬЕ КАРАДАГА (2017 Г.)
} Трощенко О.А., Ковригина Н.П., Лисицкая Е.В., Капранов С. В., Еремин И.Ю., Родионова Н.Ю.

ФГБУН «Институт морских биологических исследований имени А.О. Ковалевского РАН», 2. Севастополь, Российская Федерачия, е-таil: maricultura@mail.ru

Представлены результаты комплексных исследований в прибрежной акватории Карадагского природного заповедника и в Коктебельской бухте, проводившихся в мае и сентябре 2017 г. Изучено влияние хозбытовых стоков поселков городского типа Коктебель и Курортное на распределение гидрологических и гидрохимических полей, а также на состояние меропланктона на прибрежных станциях четырех разрезов. Показано, что термохалинные поля во время обеих съёмок были достаточно однородными. Некоторое увеличение горизонтальных градиентов наблюдалось в районе м. Мальчин. По величинам БПК 5 и окисляемости, превышающим предельно-допустимые концентрации (ПДК) и величинам коэффициентов загрязнения Кз (БПК / окисляемости), превышающим 1, выявлены районы, загрязненные хозбытовым стоком. Рассчитано содержание органического углерода (Сров) на поверхности прибрежной зоны Карадага и Коктебельской бухты и проведено сравнение с его содержанием в начальный период исследований (2004 г.). По величинам отношения Рмин:Рвал $<30 \%$ и высоким концентрациям кремния и фосфора минерального выявлено влияние азовоморских вод на гидрохимическую структуру исследуемой акватории. В мае исследован таксономический состав меропланктона прибрежной акватории Карадага. На основе расчёта парных коэффициентов корреляции рассмотрены связи между всеми изучаемыми абиотическими параметрами и количественным содержанием меропланктона. Проведено сопоставление величин общей численности меропланктона с содержанием биогенных веществ, полученных в мае на прибрежных станциях разрезов.

Ключевые слова: гидролого-гидрохимические показатели; азовоморские воды; субмаринная разгрузка; меропланктон; прибрежная зона Карадага; Черное море.

\section{Введение}

Комплексные гидролого-гидрохимические и гидробиологические исследования в районе Карадага, как и в других прибрежных водах Крыма, всегда актуальны, имеют научный и практический интерес. Несмотря на то, что на территории заповедника не производится какая-либо хозяйственная деятельность, отнести прилегающую к нему акваторию к «чистым» прибрежным водам на сегодняшний день проблематично. Постоянно действующие сточные хозбытовые воды от п.г.т. Курортное и Коктебель, сток реки Отузки, дренажные и ливневые воды оказывают существенное влияние на изменение гидрохимического режима характерного для незагрязненной прибрежной зоны моря. Исследования прошлых лет выявили, что наиболее чувствительным индикатором сточных вод оказалась величина перманганатной окисляемости, зависящая от органического вещества стоков, поступающих в море (Ковригина и др., 2007). Сопоставление гидрохимических данных с гидробиологическими позволило выявить в узкой прибрежной зоне районы, находящиеся под локальным влиянием хозбытовых стоков, где отмечено превышение ПДК по величинам окисляемости и БПК5, понижение содержания кислорода и повышение концентраций биогенных веществ. Там же зафиксировано снижение видового состава и общей численности меропланктона, что свидетельствует о негативном влиянии хозбытовых стоков на жизнедеятельность гидробионтов (Ковригина и др., 2017).

Целью настоящей работы является изучение особенностей пространственного распределения и временной изменчивости основных гидролого-гидрохимических 47 
показателей и меропланктона в мае и сентябре 2017 г. и оценка влияния хозбытовых стоков на прибрежную зону между Коктебельской бухтой и п.г.т. Курортное.

\section{Материалы и методы}

В 2017 г. в прибрежной зоне Карадага проведены две комплексные съемки: 30 мая и 14 сентября. Пробы отбирали по уже существующей с 2012 г. сетке станций, которая охватывала четыре разреза по нормали к береговой линии - от причала бухты Коктебель, от мыса Мальчин, от бухты Сердоликовой и от Биостанции. Кроме разрезов пробы отбирали на прибрежных станциях в районах устья реки Отузки - ст. 21 и очистных сооружений - ст.22 (рис. 1). Дополнительно в сентябрьской съёмке с берега в 2-х метровой полосе моря отобраны четыре пробы: в районе камней Кузьмича, на западной границе заповедника, на пляже и в районе стока из дельфинария.

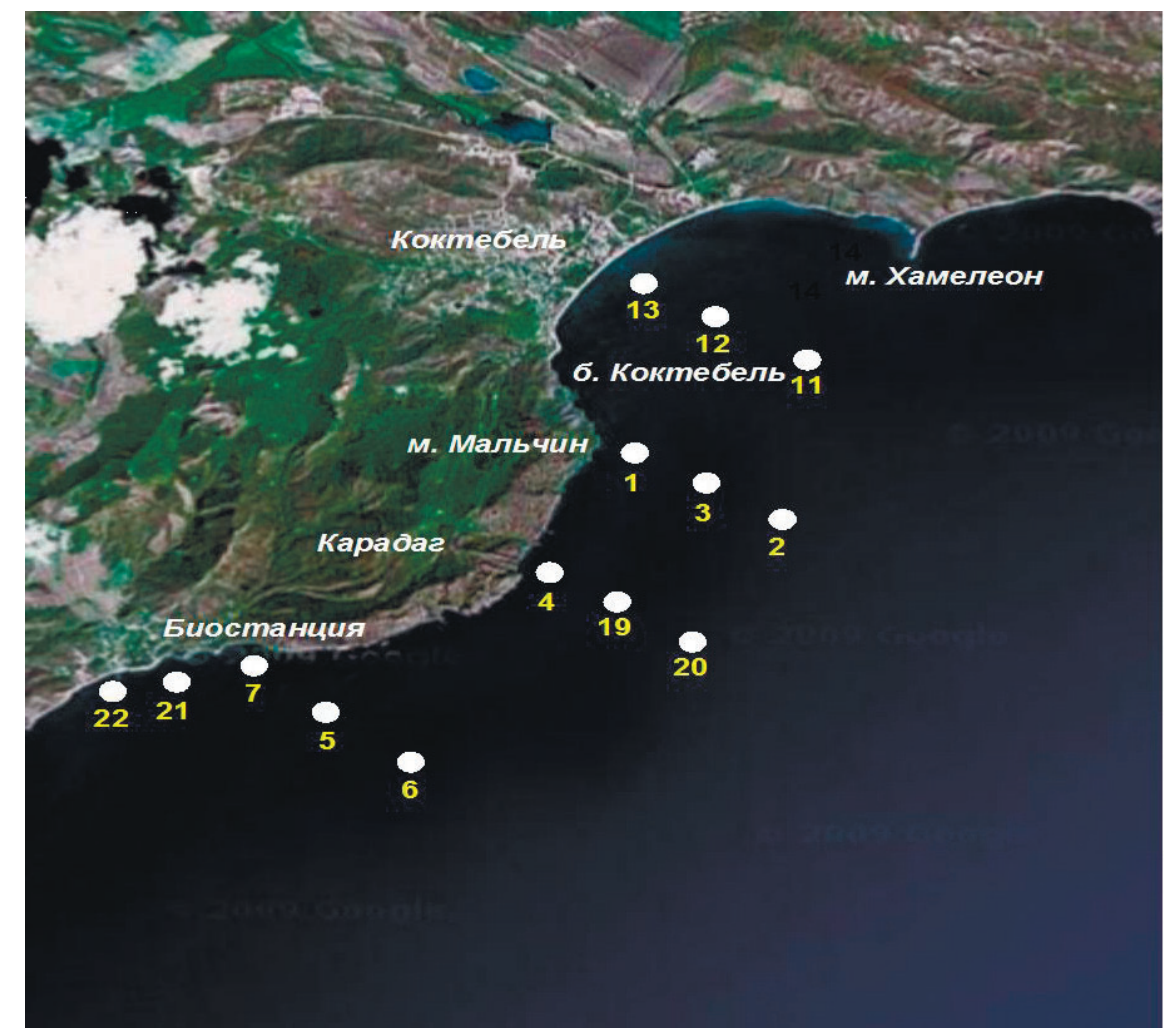

Рис. 1. Схема станций отбора проб на Карадагском взморье в 2017 г.

В комплекс гидролого-гидрохимических исследований входило измерение температуры, солености, растворенного кислорода, биохимического потребления кислорода на пятые сутки (БПК $)$, перманганатной окисляемости в щелочной среде, кремния, органических и неорганических форм азота и фосфора. Пробы отбирали на 14 станциях с поверхности и у дна. Всего отобрано 60 проб и выполнено около 575 гидролого-гидрохимических анализов, проведенных согласно общепринятым методикам (Руководство,1977; Методы, 1988; Методические, 1966). По величинам окисляемости рассчитано содержание органического углерода (Сров) на поверхности в прибрежной зоне Карадагского природного заповедника и в Коктебельской бухте (Скопинцев, 1975). Коэффициент загрязнения Кз, равный отношению величин БПК 5 к окисляемости, также рассчитан по Скопинцеву (Скопинцев, 1975). Гидробиологические исследования включали изучение таксономического состава и численности меропланктона на прибрежных станциях. Меропланктон собирали в мае в слое $10-0$ м сетью Джеди (диаметр входного отверстия 36 см, размер ячеи мельничного газа - 135 
мкм) на станциях: 13 - Коктебель, 1 - мыс Мальчин, 4 - Сердоликовая бухта, 7 - причал Биостанции. Предварительная обработка проб проведена на живом материале путем тотального подсчета личинок в камере Богорова под бинокуляром МБС-9. Для дальнейшей обработки пробы фиксировали 4\% раствором формалина, для идентификации личинок использовали световой микроскоп «Микмед-5». Обработка материалов выполнена в отделе аквакультуры и морской фармакологии ИМБИ РАН.

\section{Результаты и обсуждение}

Результаты съёмки 30 мая 2017 2. Весенняя съёмка 30 мая 2017 г. по термохалинным характеристикам была очень близка к съёмке предыдущего года (Ковригина и др., 2017). Диапазон изменчивости поверхностной температуры был несколько уже $-16,8-17,8^{\circ} \mathrm{C}$ (рис. 2). Температура так же плавно повышалась от Коктебельской бухты к п.г.т. Курортное. Однако, на космическом снимке (рис. 3) отчётливо видно в западной части Коктебельской бухты и в районе м. Мальчин некоторое изолированное термическое образование с повышенной температурой. Такие же образования видны на западной и восточной границах Феодосийской бухты, что говорит о сложности гидродинамики прибрежных вод.

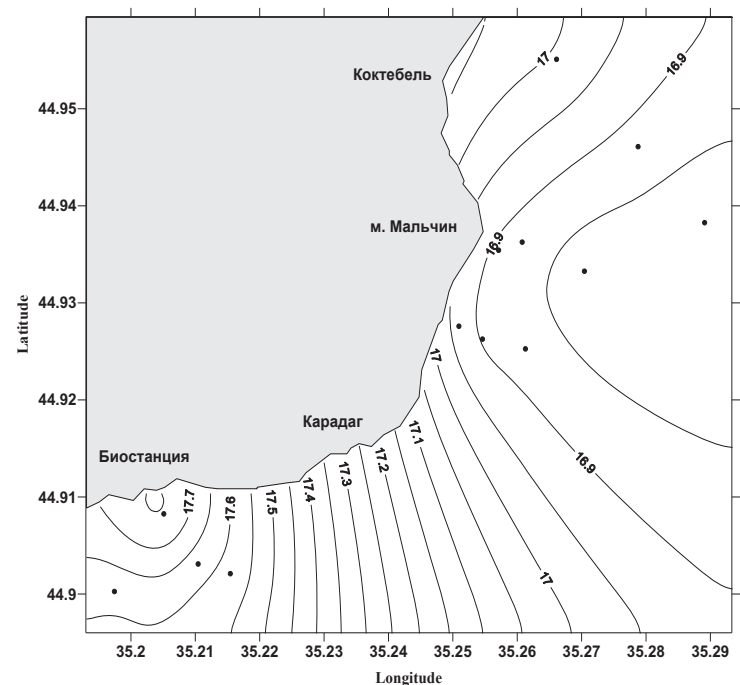

a)

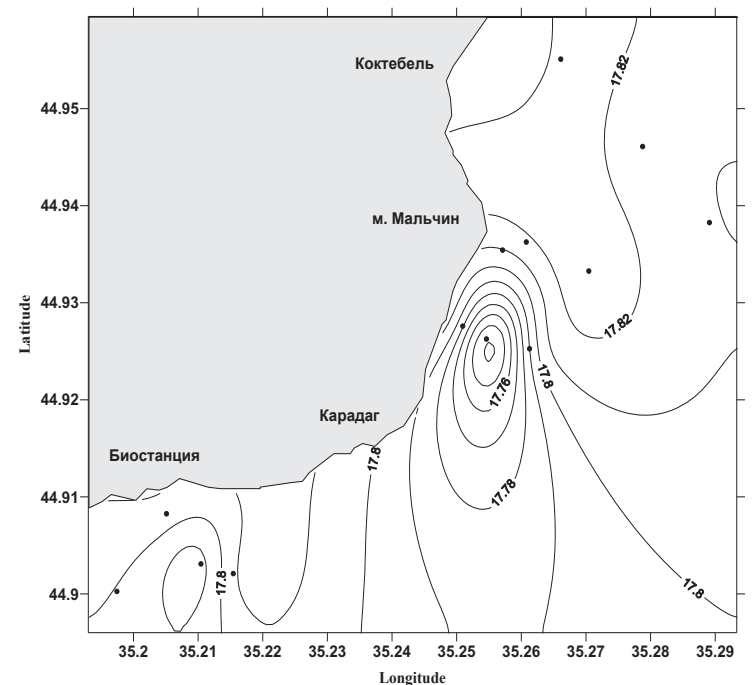

б)

Рис. 2. Распределение поверхностной температура (а) и солёности (б) 30 мая 2017.

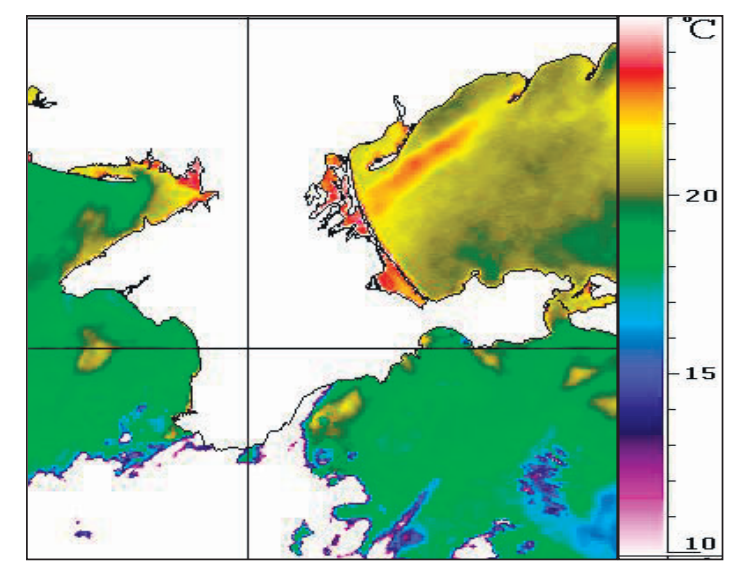

a)

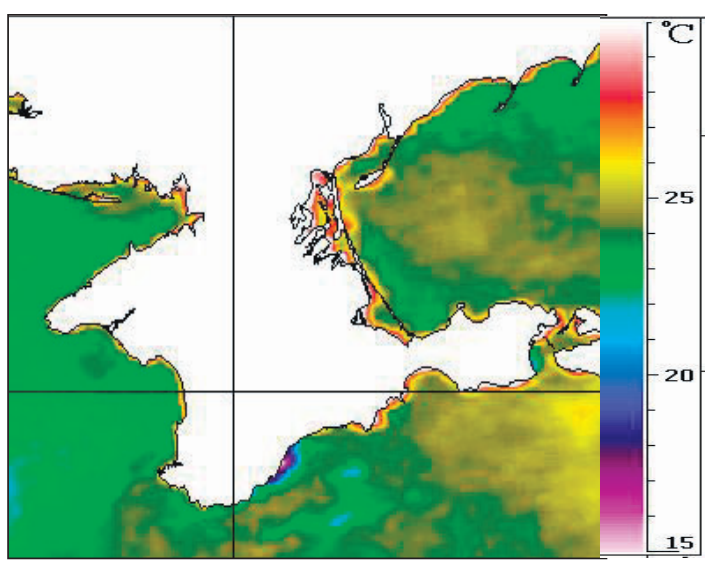

б)

Рис. 3. Поверхностная температура по данным ИСЗ NOAA: а) 30 мая 2017 г. (804), б) 14 сентября 2017 г. (13-09). Снимки взяты с официального сайта ФГБУН «Морской гидрофизический институт РАН» 
Таблица 1.

Распределение гидролого-гидрохимических показателей на Карадагском взморье 30 мая 2017 г.

\begin{tabular}{|c|c|c|c|c|c|c|c|c|c|c|c|c|c|c|}
\hline \multirow{2}{*}{$\begin{array}{l}\text { № } \\
\text { ст }\end{array}$} & \multirow{2}{*}{$\begin{array}{l}\mathrm{H} \\
\mathrm{M} \\
\end{array}$} & \multirow{2}{*}{$\begin{array}{c}\mathrm{T} \\
{ }^{\circ} \mathrm{C}\end{array}$} & \multirow{2}{*}{$\begin{array}{c}\mathrm{S} \\
\% 0\end{array}$} & \multicolumn{2}{|c|}{$\mathrm{O}_{2}$} & \multirow{2}{*}{$\begin{array}{c}\text { БПК } \\
\text { мг/л }\end{array}$} & $\mathrm{NO}_{2}$ & $\mathrm{NO}_{3}$ & $\mathrm{NH}_{4}$ & $\mathrm{PO}_{4}$ & $\mathrm{Si}$ & $\mathrm{P}_{\mathrm{opr}}$ & $\mathrm{N}_{\text {opr }}$ & \multirow{2}{*}{$\begin{array}{l}\text { Окис } \\
\text { мГО/л }\end{array}$} \\
\hline & & & & $\mathrm{M} \Omega / \Omega$ & $\%$ & & \multicolumn{7}{|c|}{ мКг/л } & \\
\hline 14 & 0 & & & 6,41 & & 2,50 & 0,6 & 3,9 & 8,3 & 3,9 & 232 & 7,6 & 716 & 2,00 \\
\hline 13 & 0 & 17,00 & 17,83 & 6,50 & 107,1 & 1,94 & 0,4 & 4,8 & 11,8 & 2,8 & 169 & 9,0 & 1292 & 2,64 \\
\hline 13 & 10 & 15,42 & 17,63 & 6,41 & 102,1 & & 0,7 & 4,1 & & 2,5 & 202 & & & \\
\hline 12 & 0 & 16,88 & 17,81 & 6,35 & 104,3 & 2,18 & 0,3 & 3,5 & 13,6 & 2,8 & 171 & 7,5 & 1449 & 4,02 \\
\hline 12 & 20 & 15,00 & 17,73 & 6,67 & 105,4 & & 1,1 & 2,5 & & 3,5 & 185 & & & \\
\hline 11 & 0 & 16,82 & 17,81 & 6,36 & 104,4 & 1,56 & 0,4 & 3,1 & 12,4 & 2,1 & 213 & 7,8 & 1094 & 2,94 \\
\hline 11 & 30 & 13,50 & 17,82 & 6,63 & 101,6 & & 0,4 & 4,9 & & 2,1 & 197 & & & \\
\hline 2 & 0 & 16,82 & 17,83 & 6,41 & 101,4 & 2,10 & 0,2 & 3,6 & 11,2 & 2,5 & 210 & 12,3 & 1311 & 4,49 \\
\hline 2 & 30 & 11,60 & 17,92 & 6,96 & 116,7 & & 2 , & 2,3 & & 7,0 & 230 & & & \\
\hline 3 & 0 & 16,88 & 17,82 & 6,36 & 104,5 & 1,84 & 0,4 & 2,8 & 13,0 & 2 & $\begin{array}{ll}199 \\
\end{array}$ & 13,4 & 1699 & 3,00 \\
\hline 3 & 24 & 12,00 & 17,89 & 6,67 & 98,9 & & 2,4 & 3,9 & & 6,3 & 264 & & & \\
\hline 1 & 0 & 16,88 & 17,81 & 6,39 & 104,9 & 1,74 & 0,4 & 3,3 & 11,8 & 2,1 & 168 & 7,1 & 1236 & 3,63 \\
\hline 1 & 15 & 15,80 & 17,74 & 6,53 & 105,0 & & 0,6 & 6,9 & & 1,8 & 212 & & & \\
\hline 4 & 0 & 16,92 & 17,81 & 6,74 & 110,9 & 1,69 & 0,6 & 4,7 & 14,2 & 1,4 & 172 & 12,6 & 1207 & 4,22 \\
\hline 4 & 15 & 15,30 & 17,77 & 6,56 & 104,2 & & 1,6 & 7,8 & & 2,1 & 183 & & & \\
\hline 20 & 0 & 16,88 & 17,81 & 6,57 & 108,0 & 1,60 & 0,4 & 3,4 & 12,4 & 1,4 & 165 & 7,4 & 1301 & 3,57 \\
\hline 20 & 30 & 10,90 & & 6,46 & 95,3 & & 0,8 & 5,5 & & 1,4 & 89 & & & \\
\hline 19 & 25 & 12,50 & & & & & 0,5 & 2,3 & & 1,8 & 179 & & & \\
\hline 6 & 0 & 17,60 & 17,82 & 6,38 & 106,4 & 1,77 & 0,5 & 3,0 & 31,9 & 1,8 & 216 & 7,5 & 2384 & 4,52 \\
\hline 6 & 30 & 12,10 & 17,90 & 6,72 & 99,9 & & 0,9 & 12,4 & & 3,5 & 225 & & & \\
\hline 5 & 0 & 17,60 & 17,77 & 6,37 & 106,1 & 1,55 & 0,7 & 2,4 & 14,2 & 1,1 & 165 & 63,4 & 2402 & 4,31 \\
\hline 5 & 17 & 15,70 & 17,77 & 6,70 & 107,4 & & 1,1 & 2,0 & & 2,1 & 164 & & & \\
\hline 7 & 0 & 17,80 & 17,81 & 6,31 & 105,7 & 1,70 & 0,5 & 2,1 & 13,0 & 1,1 & 162 & 5,9 & 2180 & 3,65 \\
\hline 7 & 10 & 16,50 & 17,79 & 6,42 & 104,6 & & 0,7 & 2,5 & & 2,1 & 155 & & & \\
\hline 21 & 0 & 17,60 & 17,80 & 6,54 & 109,1 & 1,46 & 0,6 & 3,6 & 13,6 & 2,5 & 154 & 11,2 & 1034 & 2,75 \\
\hline 21 & 3 & 17,60 & 17,74 & 6,75 & 112,5 & & 0,6 & 2,4 & & 1,8 & 159 & & & 3,14 \\
\hline
\end{tabular}

Вертикальная термохалинная структура соответствует среднемноголетним показателям (табл. 1). В поверхностном слое идет формирование верхнего квазиоднородного слоя (ВКС). Его мощность колеблется в пределах 3-5 м. Глубже располагается сезонный термоклин $(\mathrm{CT})$ с градиентами $0,1-0,2^{\circ} \mathrm{C} / \mathrm{M}$

Распределение поверхностной солёности имеет более сложный характер (рис. 2). Однако, учитывая узкий диапазон изменчивости $(17,68-17,83 \%)$, можно говорить о значительной халинной однородности поверхностного слоя. «Сложность» в горизонтальной структуре связана с некоторым понижением солености на траверзе Сердоликовой бухты. Таким образом, в районе м. Мальчин мы также наблюдаем некоторое увеличение халинных градиентов. С глубиной солёность почти не меняется.

Величины абсолютного содержсания кислорода на всей исследуемой акватории в слое 0-30 м изменялись от 6,31 до 6,96 мл/л (рис. 4). Минимальное содержание отмечено на поверхности в районе Биостанции (ст. 7), а максимальное - на глубине 30 м. в районе мыса Мальчин (ст. 2). Отклонения от средней по слою величине (6,53 мл/л) были незначительны и составляли 0,22 мл/л в сторону понижения и 0,43 мл/л в сторону повышения содержания кислорода. Величины относительного содержания кислорода изменялись от 95 до 117\% насыщения при средней для слоя величине, равной 105\% насыщения (рис. 4). На придонных горизонтах ст. 3, 20 и 6 отмечено недонасыщение кислородом, величина которого достигало 4.7\% (табл.1).

Величины БПК 5 изменялись от 1,46 до 2,50 мг/л при среднем значении 1,81 мг/л (рис. 4). Превышение предельно-допустимой концентрации, равной 2,0 мг/л по рыбохозяйственным нормативам, наблюдали на поверхности в Коктебельской бухте (2,50 мг/л и 2,10 мг/л), а также в районе м. Мальчин (2,10 мг/л). 

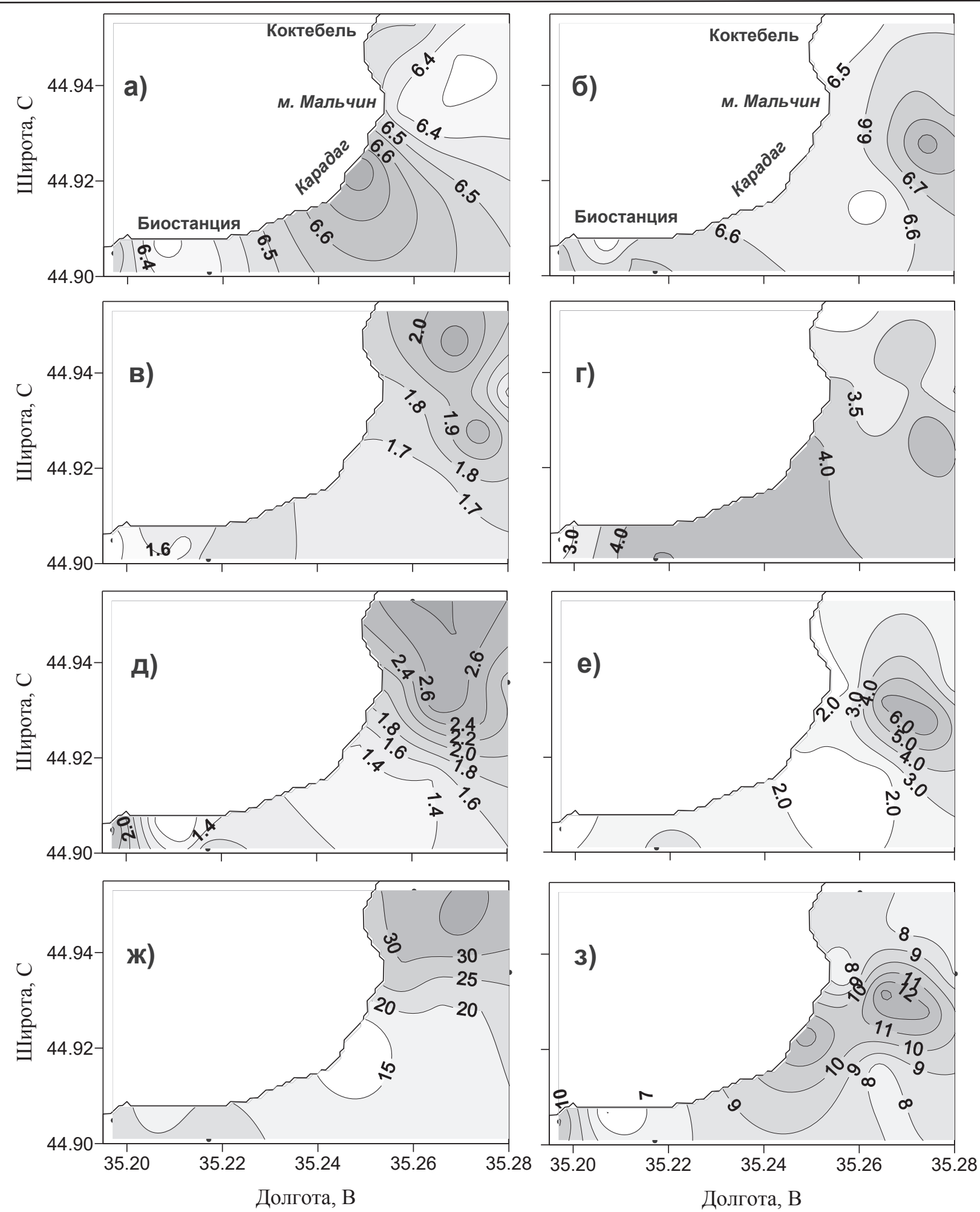

Рис. 4. Распределение г/х показателей 30 мая 2017 г.: а) кислород, мл/л (поверхность), б) кислород, мл/л (дно), в) БПК, мГ/л (поверхность), г) окисляемость, мГО/л

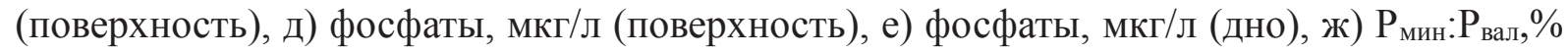
(поверхность), з) фосфор органический, мкг/л (поверхность).

Превышение ПДК свидетельствует о загрязнении этих районов хозбытовыми стоками. Влияние стоков от п. Курортное в районе Биостанции подтверждают высокие величины орг на ст. 7 (2180 мкг/л), на ст.6 (2384 мкг/л) и на ст. 5 (2402 мкг/л). Максимальная концентрация Рорг на ст. 5 (63,4 мкг/л) также является подтверждением 
влияния хозбытового стока от п.г.т. Курортное в районе Биостанции (рис. 4).

Перманганатная окисляемость в щеелочной среде имела высокие величины: от 2,00 до 4,49 мг/л, которые на 5-ти из 14 станций превышали ПДК, равную 4,0 мгО/л по рыбохозяйственным нормативам. Средняя величина окисляемости для поверхности составила 3,49 мгО/л и была ниже ПДК. Распределение величин окисляемости на поверхности представлено на рисунке 4. Для оценки влияния хозбытовых стоков на состояние прибрежной акватории мы привлекли коэффициент загрязнения (Кз), предложенный Скопинцевым как отношение величин БПК 5 к окисляемости. Его значения $>1$ свидетельствуют о неблагополучном санитарном состоянии акватории моря (Скопинцев, 1975). В нашем случае, во время съёмки 30 мая, коэффициент загрязнения изменялся от 0,36 (в районе Биостанции) до 1,25 (в бухте Коктебель). Величина Кз $>1$ отмечена только на одной станции из 13-ти; среднее значение Кз для поверхности составило 0,55, что позволяет считать исследуемую акваторию в мае 2017 г. «незагрязнённой».

Содержание растворенного органического вещества (Сров), рассчитанное для поверхности по величинам окисляемости, изменялось от 5,88 до 13,29 мгС/л при средней величине равной 10,33 мгС/л (табл. 2). Минимальное содержание Сров отмечено в Коктебельской бухте, максимальное - в районе Биостанции. В майской съемке на всей акватории исследований интервал изменчивости величин Сров практически совпадает с интервалом Сров, полученным нами в предыдущем году $(7,09$ - 13,85 мгС/л). На этом основании можно сделать вывод об отсутствии накопления растворенного органического вещества в исследуемый период.

Таблица 2

Содержание растворенного органического вещества (Сров) 30.05.2017 г.

\begin{tabular}{|c|c|c||c|c|c|}
\hline № станции & Окисляемость, мг О/л & Сров, мг С/л & $\mathrm{N}$ станции & Окисляемость, мг О/л & Сров, мг С/л \\
\hline 14 & 2,00 & 5,88 & 4 & 4,22 & 12,41 \\
\hline 13 & 2,64 & 7,76 & 20 & 3,57 & 10,50 \\
\hline 12 & 4,02 & 11,82 & 19 & - & - \\
\hline 11 & 2,94 & 8,64 & 6 & 4,52 & 13,29 \\
\hline 2 & 4,49 & 13,20 & 5 & 4,31 & 12,68 \\
\hline 3 & 3,00 & 8,82 & 7 & 3,65 & 10,74 \\
\hline 1 & 3,63 & 10,68 & 21 & 2,75 & 8,09 \\
\hline
\end{tabular}

Биогенные вещества характеризовались довольно низкими величинами и сравнительно равномерным распределением, как по горизонтали, так и по вертикали. Концентрация фосфатов в слое изменялась от 1,1 до 7,0 мкг/л; максимальная концентрация (7,0 мкг/л) отмечена в придонном слое на ст. 2 (район м. Мальчин), при средней для этого слоя величине, равной 2,9 мкг/л (рис.4).

Средняя концентрация фосфатов на поверхности в Коктебельской бухте (2,9 мкг/л) была выше, чем на поверхности акватории Карадагского природного заповедника (1,8 мкг/л), что указывает на возможное влияние азовоморских вод. Распределение кремния с востока на запад было аналогично распределению фосфатов; средняя его величина для Коктебельской бухты (195 мкг/л) была выше средней для поверхности Карадага (178 мкг/л), что подтверждает влияние азовоморских вод во время съёмки. Более четко это влияние можно проследить по величинам процентного отношения минеральной формы фосфора к валовой (Рмин:Рвал). В нашем случае величины этого отношения изменялись в пределах от 1,70 до 33,9\% (рис. 4) и на 12 станциях из 13 имели низкие (<30\%) значения отношения Рмин:Рвал, свидетельствующие о влиянии азовоморских вод практически на всей акватории исследований.

Концентрации кремния в слое изменялись в пределах от 89 до 264 мкг/л; повышенные его величины отмечены на придонных горизонтах ст. 2 (230) и ст. 6 (225 
мкг/л). Максимальная величина также зафиксирована в придонном горизонте на ст. 3 (м. Мальчин). Одновременно на ст. 3 и ст. 6 в придонном слое наблюдали понижение величин насыщения кислородом по сравнению с поверхностью на 7 и $6 \%$ соответственно. Кроме того, на ст. 3 в придонном слое отмечена максимальная концентрация нитритного азота (2,4 мкг/л) и повышенная концентрация фосфатов (6,3 мкг/л); а на ст.6 наблюдали также максимальную (12,4 мкг/л) концентрацию нитратов (рис. 5). Такая картина аномального распределения биогенных веществ и растворенного кислорода в придонном слое подтверждает присутствие источников пресных вод подземного происхождения в этих районах, выявленных нами в предыдущие годы (Ковригина, и др., 2009).
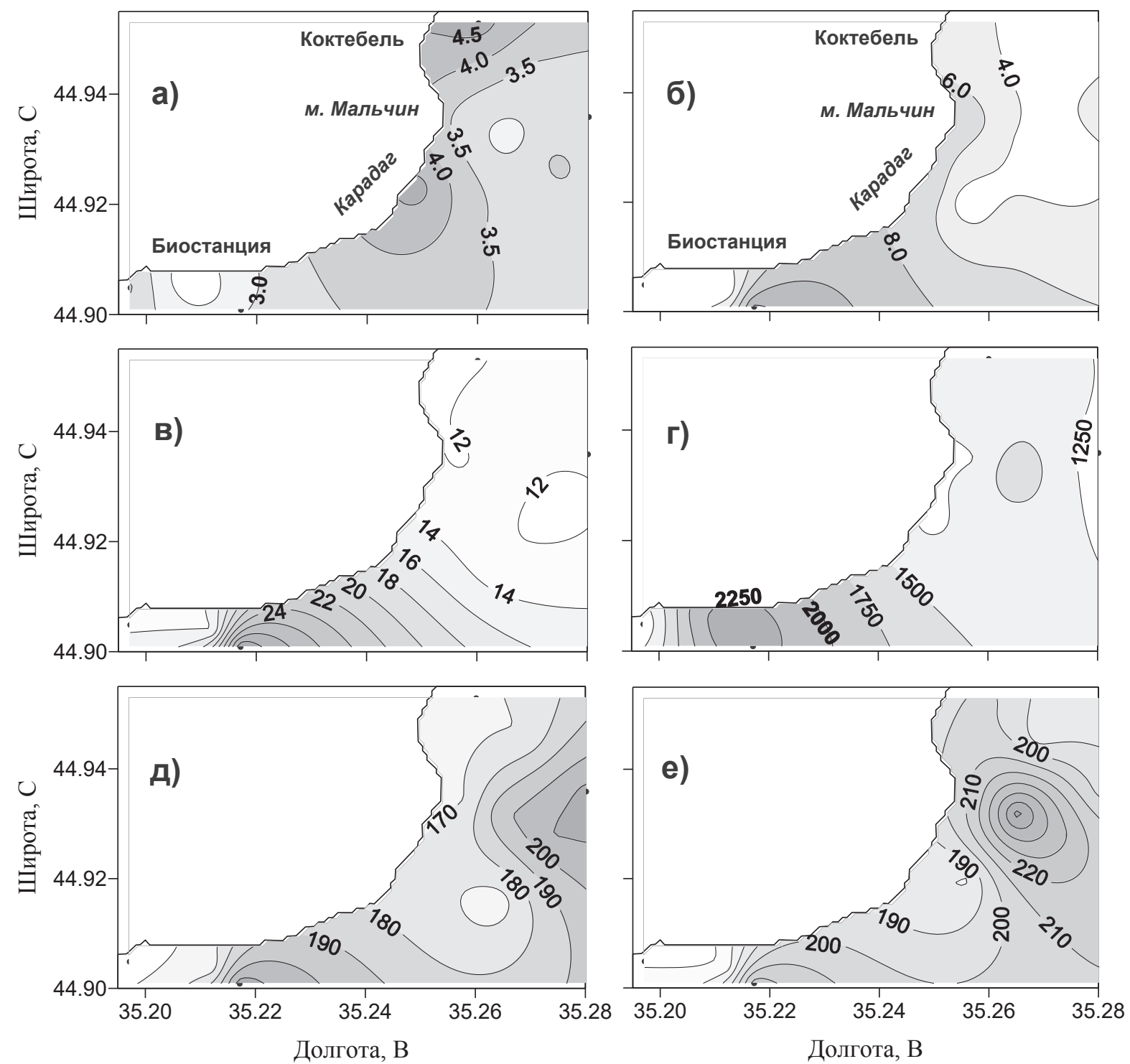

Рис. 5. Распределение биогенных веществ 30 мая 2017 г. а) нитраты, мкг/л (поверхность), б) нитраты, мкг/л (дно), в) азот аммонийный, мкг/л (поверхность), г) азот органический, мкг/л (поверхность), д) кремний, мкг/л (поверхность), е) кремний, мкг/л (дно)

Величины нитратов в слое изменялись от 2,3 до 12,4 мкг/л при средних значениях равных 3,4 на поверхности и 4,6 мкг/л в придонном слое. Повышенные концентрации на поверхности восточной части акватории подтверждают влияние азовоморских вод, а повышенные величины нитратов в придонном слое на ст. 1 (6,9 мкг/л) и на ст. 4 (7,8 мкг/л) являются, по-видимому, результатом присутствия 
источников пресных вод подземного происхождения. Распределение концентраций нитратов на поверхности и в придонном слое представлено (рис. 5).

Концентрации азота нитритного и аммонийного изменялись от 0,2 до 2,4 мкг/л и от 8,3 до 31,9 мкг/л соответственно. Максимальная концентрация аммонийного азота отмечена на мористой станции (ст. 6) разреза от Биостанции и совпадает с максимальной величиной окисляемости и растворенного органического вещества $(13,29$ мкгС/л), что также свидетельствует о некотором органическом загрязнении.

Меропланктон. При прогреве воды до $16-17^{\circ} \mathrm{C}$ начинают размножаться многие виды донных беспозвоночных, что отражается на видовом составе и численности меропланктона. Во время майской съемки численность меропланктона в прибрежной

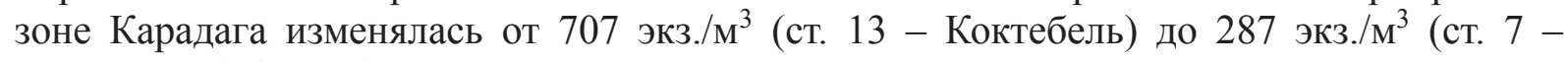
Биостанция) (рис. 6). У мыса Мальчин и в Сердоликовой бухте суммарное количество личинок составляло 526 и 448 экз./ $\mathrm{M}^{3}$ соответственно. Максимальная плотность личинок двустворчатых моллюсков (162 экз./ $\left.{ }^{3}\right)$ зарегистрирована в Коктебельской бухте. На остальных станциях она не превышала 64 экз./ $\mathrm{M}^{3}$. В планктоне зарегистрированы поздние великонхи мидии Mytilus galloprovincialis Lamarck, 1819 (до 11 экз./ $\left.\mathrm{M}^{3}\right)$, можно предположить, что к этому времени оседание мидий уже заканчивалось. Великонхи Cardiidae встречались в небольшом количестве (до 41 экз./ ${ }^{3}$ ). Отмечены личинки двустворчатого моллюска-вселенца в Черное море мии Муа arenaria Linnaeus, 1758 - до 62 экз./ $\mathrm{M}^{3}$ в Коктебельской бухте, у мыса Мальчин их

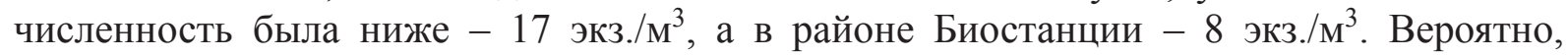
личинки мии были принесены с азовоморскими водами, влияние которых выявлено нами по гидрохимическим показателям. Численность велигеров брюхоногих моллюсков (представителей семейства Rissoidae) изменялась от 46 экз. $\mathrm{M}^{3}$ (район Биостанции) до 174 экз./м³ (район м. Мальчин). Личинки находились на ранних стадиях развития, что подтверждает начало размножения многих видов Gastropoda в этот период. Необходимо отметить, что в мае прошлого года видовой состав и численность личинок моллюсков в акватории Карадага были аналогичными (Ковригина и др., 2017).

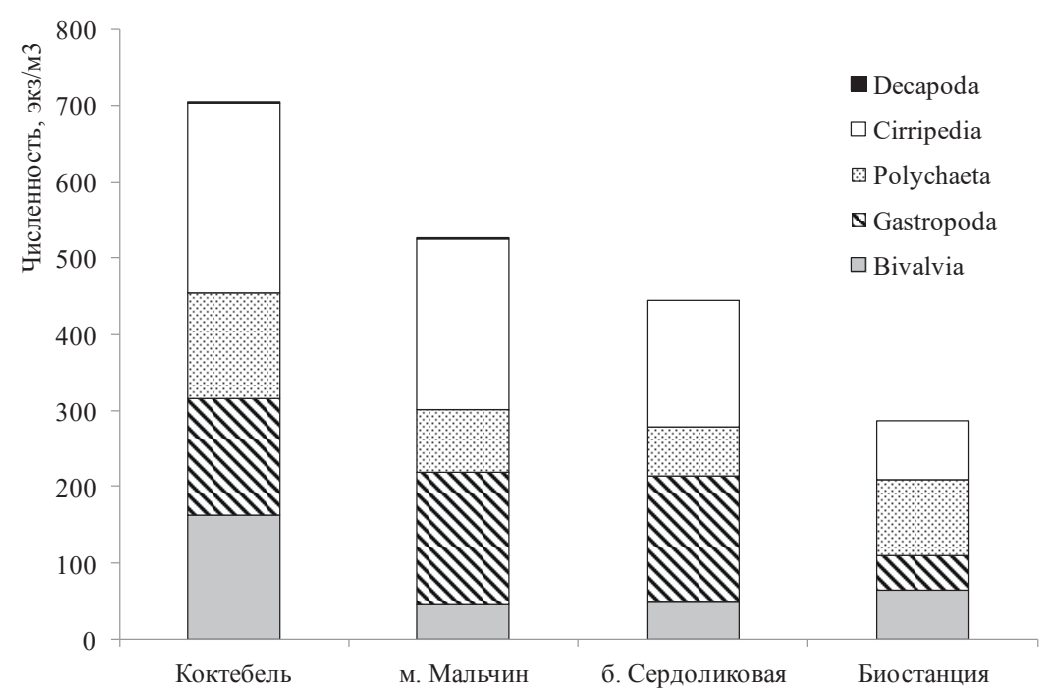

Рис. 6. Таксономическая структура меропланктона в акватории Карадага 30.05.2017 г.

Максимальная плотность личинок Polychaeta отмечена в Коктебельской бухте 138 экз./ $\mathrm{M}^{3}$. Многощетинковые черви, в основном, были представлены личинками

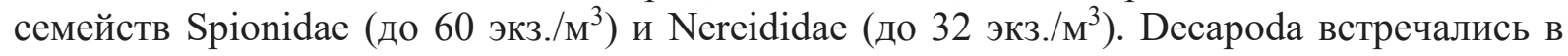
незначительном количестве. Единично отмечены личинки крабов, массовое размножение креветок еще не началось - их личинки в пробах не обнаружены. По численности в меропланктоне доминировали науплиусы усоногого рака Amphibalanus 
improvisus Darwin, 1854. В Коктебельской бухте и у мыса Мальчин их количество достигало 223 и 250 экз./ $\mathrm{M}^{3}$ соответственно, в Сердоликовой бухте - 166 экз./ $\mathrm{M}^{3}$, в районе Биостанции - 78 экз./ $\mathrm{M}^{3}$.

Для определения возможных взаимозависимостей между абиотическими и биотическими (общая численность меропланктона) параметрами были рассчитаны коэффициенты парной корреляции в майских съёмках за последние 10 лет (табл. 3). Для анализа учитывались только достоверные значения, соответствующие 95\% доверительному интервалу. При этом мы сознаём, что наличие высоких значений корреляции не говорит о причинно-следственных связях, но даёт пищу для дальнейших размышлений.

Таблица 3

Коэффициенты парной корреляции между абиотическими и биотическими параметрами

\begin{tabular}{|c|c|c|c|c|c|c|c|c|c|c|c|}
\hline & & & & & & & & & & & \\
\hline Май & $\begin{array}{l}0 \\
0 \\
\mapsto\end{array}$ & $\begin{array}{l}d \gtreqless \\
\dot{s}\end{array}$ & $\begin{array}{l}\frac{5}{5} \\
\frac{5}{5} \\
\text { i }\end{array}$ & $\begin{array}{l}\text { dீ } \\
\hat{\delta}\end{array}$ & 光占县 & $\begin{array}{l}O_{Z} \\
\end{array}$ & $\stackrel{0}{Z}$ & O & $\bar{n}$ & ڤ̆ & $\begin{array}{l}\dot{5} \\
\text { 它 } \\
\text { 客 }\end{array}$ \\
\hline $\mathrm{T},{ }^{\circ} \mathrm{C}$ & & $-0,19$ & $-0,52$ & $-0,13$ & $-0,33$ & $-0,15$ & $-0,05$ & 0,27 & 0,04 & 0,38 & 0,04 \\
\hline S, \%o & $-0,19$ & & $-0,43$ & $-0,56$ & $-0,51$ & $-0,22$ & $-0,18$ & $-0,95$ & 0,88 & $-0,36$ & $-0,56$ \\
\hline $\mathrm{O}_{2}, \mathrm{MI} / \Omega$ & $-0,52$ & $-0,43$ & & 0,92 & 0,63 & 0,12 & 0,38 & 0,32 & $-0,50$ & 0,12 & 0,34 \\
\hline $\mathrm{O}_{2}, \%$ & $-0,13$ & $-0,56$ & 0,92 & & 0,56 & 0,06 & 0,42 & 0,48 & $-0,55$ & 0,31 & 0,41 \\
\hline БПК 5, мГ/л & $-0,33$ & $-0,51$ & 0,63 & 0,56 & & 0,31 & 0,25 & 0,32 & $-0,44$ & $-0,03$ & 0,41 \\
\hline $\mathrm{NO}_{2}$ & $-0,15$ & $\begin{array}{c}-0,22 \\
\end{array}$ & 0,12 & 0,06 & 0,31 & & 0,37 & 0,13 & $-0,03$ & 0,24 & 0,07 \\
\hline $\mathrm{NO}_{3}$ & $-0,05$ & $-0,18$ & 0,38 & 0,42 & 0,25 & 0,37 & & 0,22 & 0,14 & 0,14 & 0,66 \\
\hline $\mathrm{PO}_{4}$ & 0,27 & $-0,95$ & 0,32 & 0,48 & 0,32 & 0,13 & 0,22 & & $-0,84$ & 0,49 & 0,57 \\
\hline $\mathrm{Si}$ & 0,04 & 0,88 & $-0,50$ & $-0,55$ & $-0,44$ & $-0,03$ & 0,14 & $-0,84$ & & $-0,36$ & $-0,31$ \\
\hline Рорг & 0,38 & $-0,36$ & 0,12 & 0,31 & $-0,03$ & 0,24 & 0,14 & 0,49 & $-0,36$ & & 0,03 \\
\hline Числ. Меропл. & 0,04 & $-0,56$ & 0,34 & 0,41 & 0,41 & 0,07 & 0,66 & 0,57 & $-0,31$ & 0,03 & \\
\hline
\end{tabular}

Если рассматривать связи между абиотическими параметрами, то можно выделить очень высокие коэффициенты корреляции между солёностью с фосфатами (коэфф. -0,95) и солёностью с кремнием (коэфф. 0,88). Это косвенно подтверждает влияние азовоморских вод на Карадагском взморье. Значимые коэффициенты корреляции для меропланктона выявлены с солёностью, нитратами и фосфатами.

На первый взгляд несколько неожиданны низкие значения коэффициентов корреляции для температуры со всеми характеристиками. Однако, нужно учитывать, что поля температуры в большинстве случаев гомогенны. Поэтому главными являются не сами значения температуры, а направленность гидрологических процессов. Так, в большинстве случаев мы имеем градиентные зоны у м. Мальчин, связанные с особенностями циркуляции вод в данном районе. Здесь же отмечаются градиентные зоны гидрохимических полей и максимальное количество меропланктона. Таким образом, нужно отметить, что для получения более значимых результатов по взаимозависимостям абиотических и биотических параметров необходимо дальнейшее накопление первичных материалов.

Результаты съёмки 14 сентября 2017 2. Съёмка, проведённая 14 сентября 2017 г., показала ещё большую термическую однородность поверхностных вод по сравнению с майской. Диапазон изменчивости температуры составлял $23,9-24,4^{\circ} \mathrm{C}$ (рис. 7). Эти значения были заметно выше (приблизительно на $2^{\circ} \mathrm{C}$ ) среднемноголетних показателей. Несмотря на незначительные пространственные градиенты поверхностной температуры, горизонтальное распределение её значений имело сложный характер зоны относительно повышенных и пониженных значений меняли друг друга. 


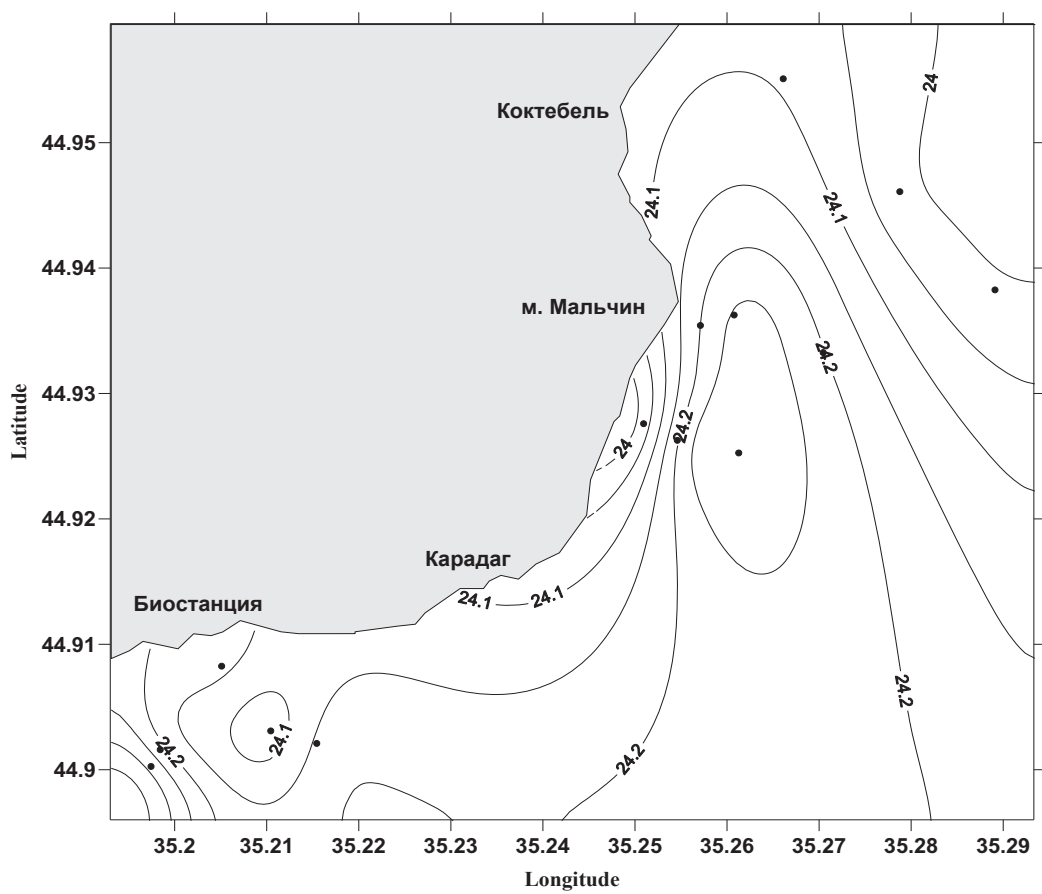

Рис.7 . Распределение поверхностной температуры 14 сентября 2017 г.

В районе Сердоликовой бухты и м. Мальчин можно выделить слабовыраженный термический круговорот. Сложность распределения поверхностной температуры в прибрежной зоне подтверждают данные космических снимков (рис. 3). Наибольшие горизонтальные градиенты наблюдались между изобатами 10 и 20 м в районе Сердоликовой бухты и м. Мальчин. С глубиной температура слабо и практически равномерно понижалась. Средний вертикальный градиент составлял $0,05^{\circ} \mathrm{C} / \mathrm{M}$, следовательно, весь изучаемый слой занимал ВКС (табл.4).

Таблица 4.

Распределение гидролого-гидрохимических показателей на Карадагском взморье 14 сентября 2017 г.

\begin{tabular}{|c|c|c|c|c|c|c|c|c|c|c|c|c|}
\hline \multirow{2}{*}{$\begin{array}{l}\text { № } \\
\text { ст }\end{array}$} & \multirow{2}{*}{$\begin{array}{l}\mathrm{H} \\
\mathrm{M}\end{array}$} & \multirow{2}{*}{$\begin{array}{c}\mathrm{T} \\
{ }^{\circ} \mathrm{C} \\
\end{array}$} & \multicolumn{2}{|c|}{$\mathrm{O}_{2}$} & \multirow{2}{*}{$\begin{array}{c}\text { БПК } \\
\text { мГ/л }\end{array}$} & $\mathrm{NO}_{2}$ & $\mathrm{NO}_{3}$ & $\mathrm{NH}_{4}$ & $\mathrm{PO}_{4}$ & $\mathrm{Si}$ & $\mathrm{P}_{\text {opr }}$ & $\mathrm{N}_{\text {opr }}$ \\
\hline & & & мл/л & $\%$ & & \multicolumn{7}{|c|}{ мКг/Л } \\
\hline 13 & 0 & 24,10 & 6,20 & 116,9 & 3,45 & 1,1 & 3,9 & 22,7 & 4,4 & 83 & 15,9 & 226 \\
\hline 13 & 10 & 23,50 & 6,16 & 115,0 & & 0,8 & 1,9 & & 4,3 & 149 & & \\
\hline 12 & 0 & 24,00 & 6,41 & 120,7 & 3,17 & 0,8 & 4,2 & 24,0 & 5,9 & 80 & 19,7 & 384 \\
\hline 12 & 21 & 23,00 & 6,01 & 111,1 & & 0,1 & 4,7 & & 4,9 & 80 & & \\
\hline 11 & 0 & 24,00 & 6,70 & 126,1 & & 0,2 & 4,9 & 10,9 & 3,9 & 126 & 13,8 & 303 \\
\hline 11 & 30 & 22,80 & 6,66 & 122,7 & & 0,7 & 2,8 & & 3,7 & 133 & & \\
\hline 2 & 0 & 24,20 & 6,08 & 114,9 & & 0,5 & 2,2 & 6,1 & 4,1 & 68 & 15,4 & 285 \\
\hline 2 & 29 & 22,70 & 5,79 & 106,3 & & 0,4 & 2,0 & & 3,5 & 151 & & \\
\hline 3 & 0 & 24,30 & 5,93 & 112,1 & 1,59 & 0,4 & 3,0 & 14,2 & 3,6 & 65 & 13,4 & 286 \\
\hline 3 & 20 & 22,60 & 6,37 & 116,9 & & 0,4 & 1,9 & & 2,3 & 85 & & \\
\hline 1 & 0 & 24,20 & & & & 0,2 & 5,4 & 7,1 & 3,2 & 50 & 13,4 & 241 \\
\hline 1 & 14 & 23,70 & 6,22 & 116,4 & & 0,1 & 2,9 & & 2,9 & 54 & & \\
\hline 4 & 0 & 23,90 & 6,20 & 116,4 & 2,65 & 0,0 & 1,8 & 5,4 & 5,8 & 97 & 12,9 & 264 \\
\hline 4 & 12 & 23,60 & 6,19 & 115,7 & & 0,2 & 1,6 & & 3,5 & 59 & & \\
\hline 19 & 0 & 24,30 & 6,43 & 121,8 & 1,91 & 0,2 & 2,1 & 13,0 & 3,9 & 81 & 11,6 & 290 \\
\hline 19 & 24 & 22,60 & 6,20 & 113,7 & & 0,1 & 4,5 & & 3,9 & 110 & & \\
\hline 20 & 0 & 24,30 & 6,48 & 122,6 & & 0,1 & 3,2 & 2,6 & 3,4 & 54 & 12,0 & 307 \\
\hline 20 & 30 & 22,60 & 5,70 & 104,5 & & 0,7 & 2,7 & & 4,9 & 190 & & \\
\hline 6 & 0 & 24,20 & 6,53 & 123,3 & & 0,4 & 1,7 & 2,1 & 3,7 & 110 & 13,3 & 384 \\
\hline 6 & 30 & 22,70 & 6,16 & 113,2 & & 0,9 & 3,2 & & 5,2 & 117 & & \\
\hline 5 & 0 & 24,00 & 6,88 & 129,6 & 2,95 & 0,6 & 2,0 & 0,9 & 3,6 & 33 & 14,4 & 359 \\
\hline
\end{tabular}




\begin{tabular}{|c|c|c|c|c|c|c|c|c|c|c|c|c|}
\hline № & $\mathrm{H}$ & $\mathrm{T}$ & \multicolumn{2}{|c|}{$\mathrm{O}_{2}$} & БПК & $\mathrm{NO}_{2}$ & $\mathrm{NO}_{3}$ & $\mathrm{NH}_{4}$ & $\mathrm{PO}_{4}$ & $\mathrm{Si}$ & $\mathrm{P}_{\mathrm{opr}}$ & $\mathrm{N}_{\text {opr }}$ \\
\hline ст & M & ${ }^{\circ} \mathrm{C}$ & мл/Л & $\%$ & мГ/Л & \multicolumn{7}{|c|}{ мкг/л } \\
\hline 5 & 19 & 23,20 & 6,26 & 116,1 & & 0,3 & 1,4 & & 4,4 & 59 & & \\
\hline 7 & 0 & 24,20 & 5,93 & 112,0 & 1,43 & 0,4 & 1,0 & 10,5 & 4,2 & 48 & 15,1 & 358 \\
\hline 7 & 9 & 23,60 & 6,68 & 124,8 & & 0,2 & 2,6 & & 4,1 & 41 & & \\
\hline 21 & 0 & 24,40 & 6,88 & 130,4 & 2,36 & 0,8 & 1,8 & 5,1 & 4,7 & 66 & 17,3 & 386 \\
\hline 21 & 4 & 23,90 & 6,90 & 129,6 & & 0,5 & 2,1 & & 5,0 & 72 & & \\
\hline 22 & 0 & 24,10 & 6,29 & 118,5 & 2,48 & 0,2 & 1,9 & 2,2 & 4,6 & 40 & 15,4 & 414 \\
\hline 22 & 4 & 24,00 & 6,37 & 119,8 & & 0,1 & 1,5 & & 2,7 & 23 & & \\
\hline
\end{tabular}

Растворенный кислород на всей акватории имел достаточно высокие значения: 5,70-6,90 мл/л (109 - 136 \% насыщения) (рис. 8). Средние величины содержания кислорода составляли 6,32 мл/л и 122 \% насыщения. Минимальное содержание кислорода $(5,70$ мл/л) отмечено в придонном слое на мористой станции 20 в Сердоликовой бухте. Практически такая же величина (5,79 мл/л) содержания растворенного кислорода зафиксирована и в придонном слое на мористой станции 2 в районе м. Мальчин. Отклонения от средней по слою величине были, незначительны: 0,58 мл/л в сторону повышения и 0,62 мл/л в сторону понижения.
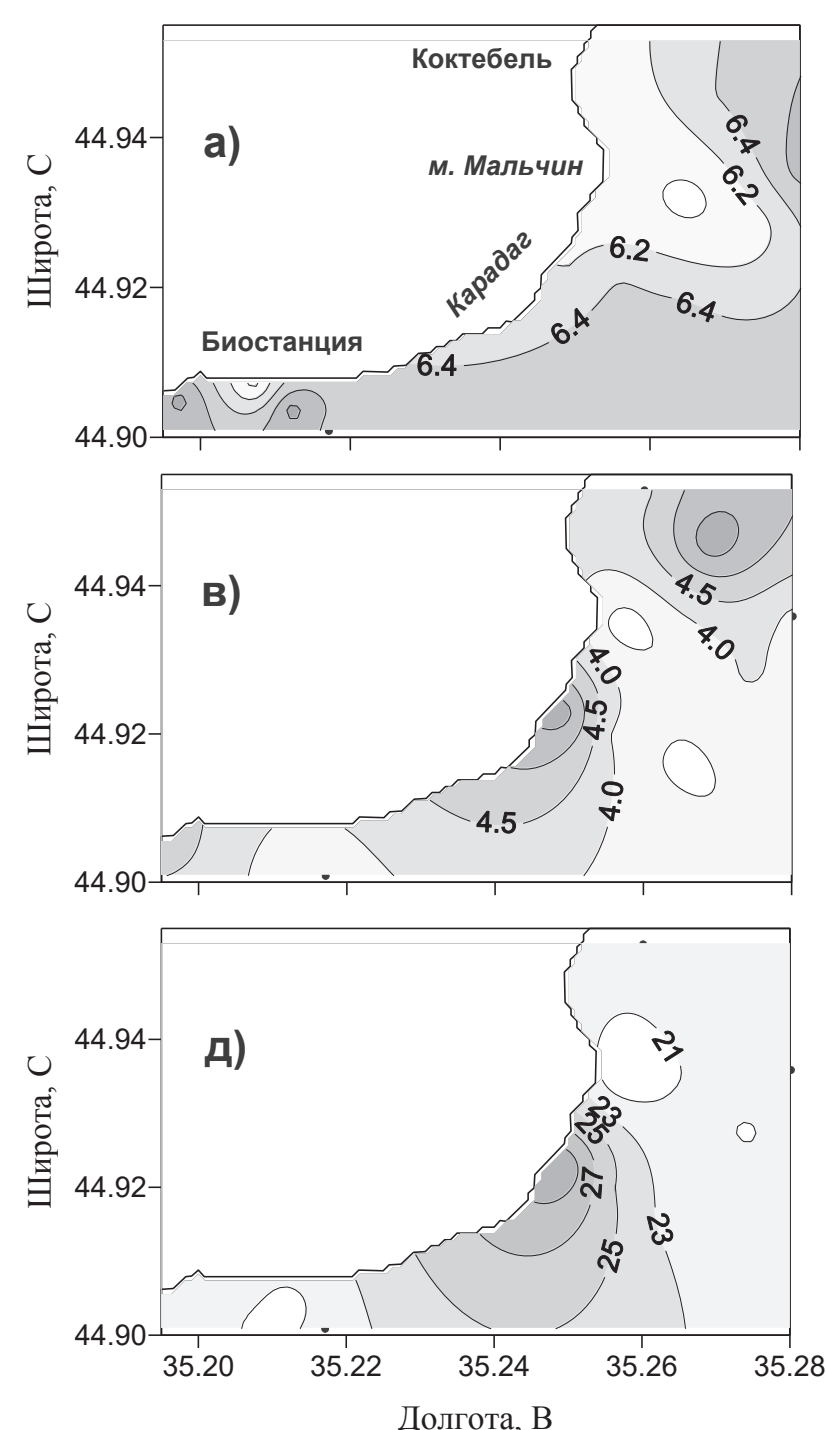
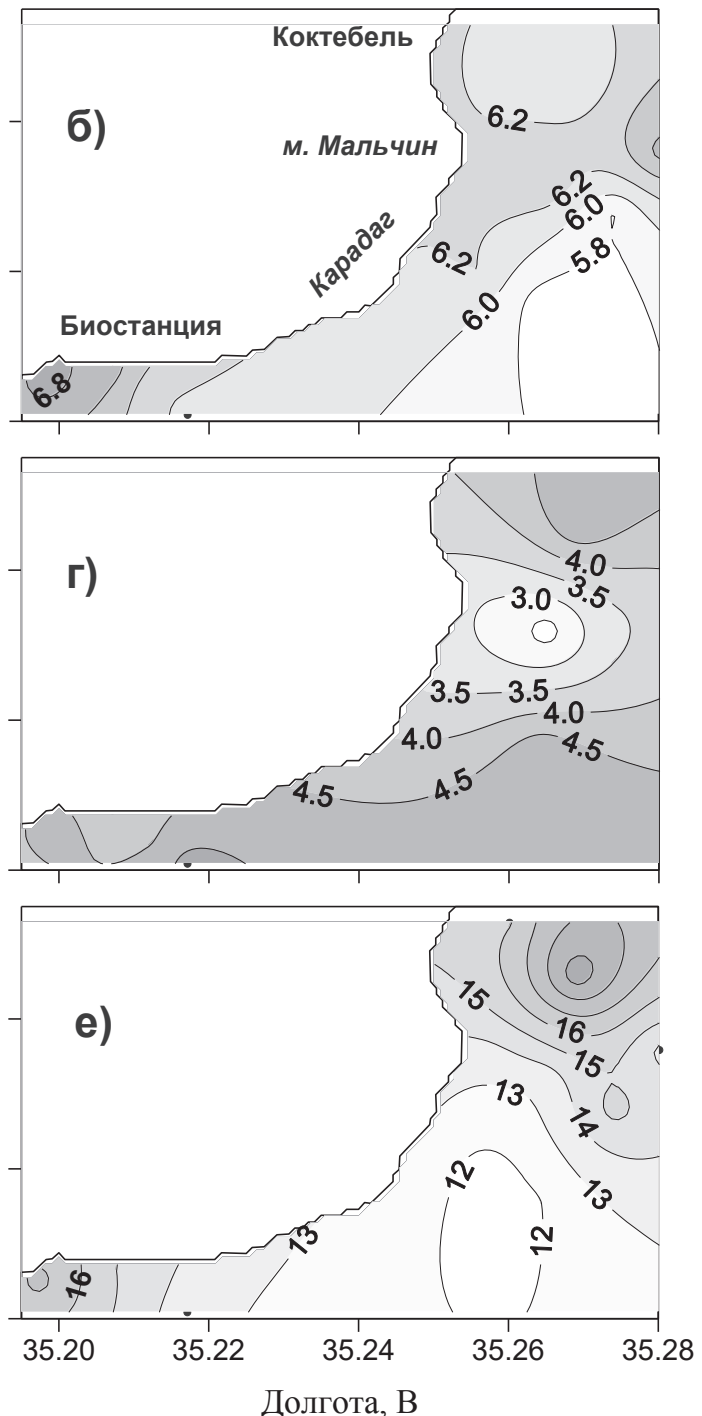

Рис. 8. Распределение г/х показателей 14 сентября 2017 г.: а) кислород, мл/л (поверхность), б) кислород, мл/л (дно), в) фосфаты, мкг/л (поверхность), г) фосфаты,

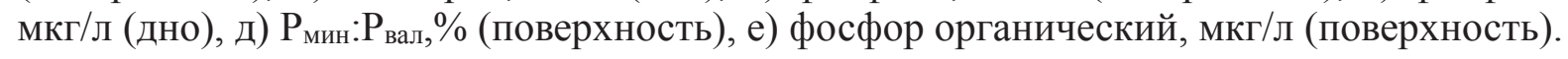


Одновременно с понижением содержания кислорода в придонном слое на этих же станциях наблюдали максимальное содержание кремния (190 мкг/л на ст. 20 и 150 мкг/л на ст.2), что свидетельствует о возможном влиянии источников пресных вод подземного происхождения (рис. 9). В исследованиях прошлых лет в указанных районах нами уже отмечалось присутствие пресных вод подземного происхождения по аномальному распределению в придонном слое кислорода и биогенных веществ (Ковригина и др., 2009).
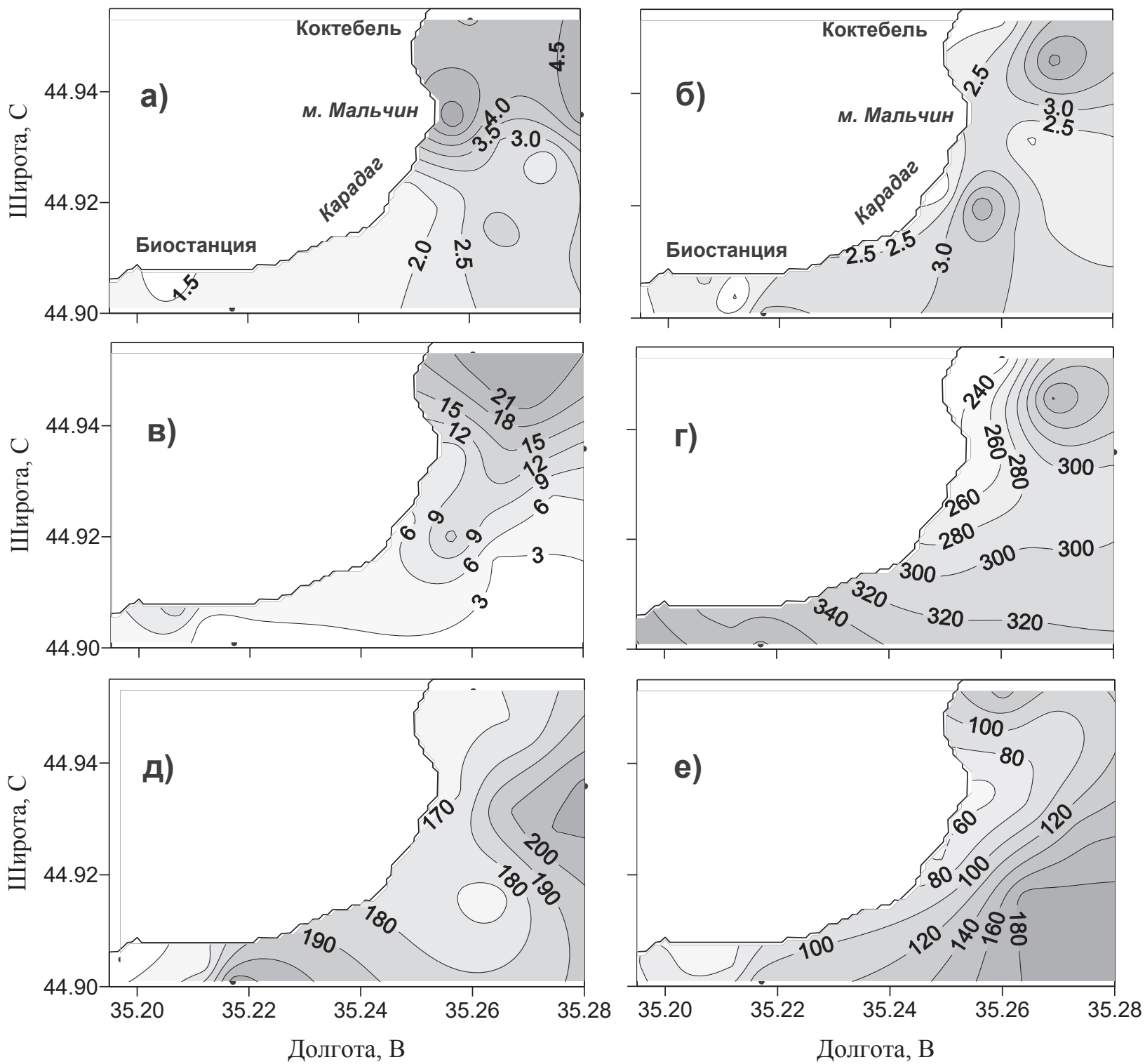

Рис. 9. Распределение биогенных веществ 14 сентября 2017 г. а) нитраты, мкг/л (поверхность), б) нитраты, мкг/л (дно), в) азот аммонийный, мкг/л (поверхность), г) азот органический, мкг/л (поверхность), д) кремний, мкг/л (поверхность), е) кремний, мкг/л (дно)

Величины БПК 5 изменялись в пределах от 1,43 до 3,45 мг/л, средняя по съёмке величина составляла 2,45 мг/л. Превышение предельно-допустимой концентрации по рыбохозяйственным нормативам, равной 2,0 мг/л отмечено на шести из девяти станций. Максимальное превышение ПДК в 1,7 раза зафиксировано в узкой прибрежной зоне на ст. 13 в бухте Коктебель, что указывает на загрязнение поверхности исследуемой акватории хозбытовыми сточными водами от п.г.т. Коктебель. Высокие величины БПК 5 
почти всегда сопровождались высоким содержанием органического вещества (Nорг и Рорг).

Влияние хозбытовых вод зафиксировано также на поверхности в Коктебельской (ст. 13 и ст. 12) бухте, в устье речки Отузки (ст. 21) и в районе Очистных (ст. 22) по высоким концентрациям биогенных веществ (рис. 9). Так, максимальные величины азота аммонийного (24 мкг/л) и фосфора органического (20 мкг/л), а также высокое содержание азота органического (384 мкг/л) отмечены на ст. 12. На поверхности ст. 13, кроме максимальной величины БПК аммонийного (23 мкг/л) и фосфора органического (16мкг/л). На ст. 21 (устье речки Отузки) наблюдали максимальное содержание фосфора органического (17 мкг/л) и высокое содержание азота органического (386 мкг/л). А на ст. 22 (район Очистных от п.г.т. Курортное) обнаружен максимум содержания азота органического (414 мкг/л).

Влияние азовоморских вод было прослежено на поверхности по повышенным концентрациям кремния в восточной части акватории. Средняя величина концентрации кремния в Коктебельской бухте составила 96 мкг/л, на акватории Карадагского природного заповедника - 65 мкг/л (рис.8). Кроме того, влияние азовоморских вод подтверждается величинами процентного отношения минеральной формы фосфора к общей Рмин:Рвал, которые изменялись от 19,3 до 31,0 \% и на всех станциях, кроме стации 4, были ниже $30 \%$. Распределение величин отношения минеральной формы фосфора к валовой (Рмин:Рвал) показано на рис.8.

Для оценки антропогенного влияния на 2-x метровую полосу моря (глубина 0,5 м) 14 сентября нами дополнительно с берега были отобраны пробы на четырёх станциях: в заповеднике (камни Кузьмича), на западной границе заповедника, на пляже и в районе стока вод из дельфинария. Распределение гидрохимических величин, полученных на этих станциях, представлено на рис. 10. В целом, оно характеризовалось снижением величин растворенного кислорода и повышением концентраций биогенных веществ по сравнению с прилегающей акваторией (ст. 7).

Средние величины растворённого кислорода в прибрежной 2-х метровой полосе моря были ниже полученных на прибрежных станциях разрезов, имеющих глубину 10 м., на 0,43 мл/л и 10 \% насыщения. Величины БПК 5 изменялись в пределах 1,44-2,82 мг/л, причём на трёх станциях из четырёх их величины превышали ПДК (2,0 мг/л); максимум отмечен в районе пляжа. Величины окисляемости были гораздо ниже ПДК по рыбохозяйственным нормативам и находились в пределах от 1,83 до 2,22 мгО/л. Величины Кз, равные отношению БПК 5 к окисляемости изменялись от 0,65 до 1,42, причём на 3-х станциях из четырёх они были $>1$, что указывает о загрязнении 2-х метровой полосы моря. И только на одной станции (камни Кузьмича), расположенной на акватории Карадагского природного заповедника, Кз имел величину <1, что характеризует район заповедника как «незагрязнённый».

Величины биогенных веществ в 2-х метровой полосе моря на глубине 0,5 м. превышали их значения в прибрежной зоне: нитраты - в 1,5 раза, азот аммонийный - в 1,6, кремний - в 1,4 раза, азот нитритный - на порядок. Такое превышение концентраций биогенных веществ в 2-х метровой полосе моря подтверждает её загрязнение хозбытовым стоком, отмеченное также по величинам БПК 5 и Кз. Среднее содержание органического вещества по величинам органического азота (орг) в 2-х метровой полосе моря и на прибрежных станциях разрезов практически не отличалось друг от друга. Поскольку величины перманганатной окисляемости имели низкие значения, то рассчитанные по ним величины растворённого органического углерода (Сорг) также были невысоки. Они изменялись в пределах от 5,38 до 6,53 мгС/л и накопления растворенного органического вещества в 2-х метровой полосе моря не показывали. 
a
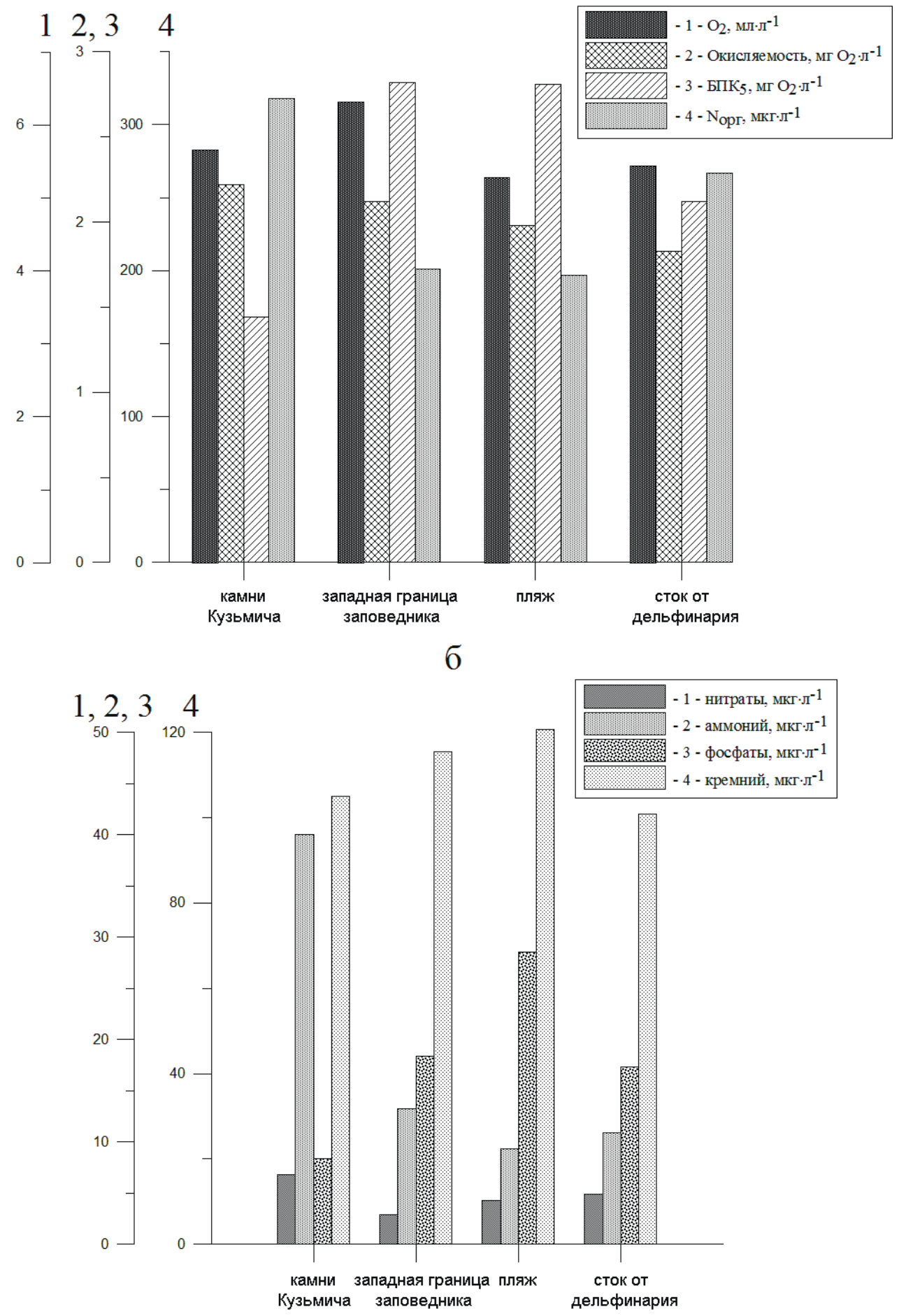

Рис. 10. Распределение гидрохимических показателей на поверхности 2-х метровой полосы моря 14 сентября 2017 г.: а) кислород, окисляемость, БПК органический азот; б) нитраты, аммоний, фосфаты, кремний.

\section{Выводы}

Май и сентябрь 2017 г. характеризовался значительной пространственной однородностью термохалинных полей. Слабовыраженные градиентные зоны отмечены в районе м. Мальчин. В этой же акватории наблюдались повышенные горизонтальные градиенты большинства гидрохимических параметров и увеличение общего количества меропланктона. 
Локальные зоны загрязнения хозбытовыми водами в мае отмечены в Коктебельской бухте и в районе м. Мальчин, в сентябре - в Коктебельской бухте, в районе стока реки Отузки и очистных сооружений п.г.т. Курортное. Они выявлены по высоким концентрациям биогенных веществ, превышению ПДК по величинам БПК 5 и окисляемости. Установлено, что накопления органического вещества по сравнению с прошлыми исследованиями не произошло.

Влияние азовоморских вод прослеживалось практически на всей акватории по величинам процентного отношения Рмин: Рвал, которое было ниже $30 \%$. Оно проявилось в мае и сентябре на 12 станциях из 13.

Снижение величин кислорода и резкое увеличение концентрации кремния в придонном слое в мае 2017 г., также, как и в мае 2016 г. отмечено на ст. 6, 3 и 2, в сентябре - на ст. 2 и на ст. 20, что указывает на возможное присутствие источников пресных вод подземного происхождения.

Видовой состав и численность меропланктона в мае 2017 г. были типичными для прибрежной акватории Карадага и аналогичными таксономической структуре, зарегистрированной в мае предыдущего года.

Получены высокие коэффициенты корреляции между солёностью и фосфатами (коэфф. -0,95), солёностью и кремнием (коэфф. 0,88), что косвенно подтверждает влияние азовоморских вод на Карадагское взморье. Выявлены значимые коэффициенты корреляции между меропланктоном с солёностью, нитратами и фосфатами.

Работа подготовлена по теме государственного задания ФГБУН ИМБИ «Исследование механизмов управления продукционными процессами в биотехнологических комплексах с целью разработки научных основ получения биологически активных веществ и технических продуктов морского генезиса», номер гос. регистрации АААА-А18-118021350003-6.

\section{Список литературы}

1. Ковригина Н.П., Павлова Е.В., Мурина В.В., Лисицкая Е.В., Смирнова Ю.Д. Гидрохимическая характеристика и меропланктон прибрежных вод Карадага (2004 г.). Экологическая безопасность прибрежной и шельфовой зон и комплексное использование ресурсов шельфа: сб. науч. тр. / НАН Украины, Морской гидрофиз. ин-т, Ин-т геологических наук, Одесский филиал Ин-та биологии южных морей. Севастополь, 2007. - Вып. 15. - С. 139-151.

2. Ковригина Н.П., Трощенко О.А., Лисицкая Е.В., Поспелова Н.В., Еремин И.Ю. Гидролого-гидрохимические и гидробиологические исследования на Карадагском взморье в теплый период 2016 г. // Труды Карадагской научной станции им. Т.И. Вяземского - природного заповедника РАН. - 2017. - № 1 (3). - С. 38-53

3. Руководство по гидрологическим работам в океанах и морях. - Л.: Гидрометеоиздат, 1977. $-725 \mathrm{c}$.

4. Методы гидрохимических исследований основных биогенных элементов. - М.: ВНИРО, 1988. - 119 с

5. Методические указания № 30. - М.: Гидрометеоиздат, 1966. - 39 с

6. Скопинцев Б.А. Формирование современного химического состава вод Черного моря. - Л.: Гидрометеоиздат, 1975. - 335 с.

7. Ковригина Н.П., Трощенко О.А., Щуров С.В. Особенности пространственного распределения гидролого-гидрохимических показателей прибрежной акватории Карадага в современный период (2005 - 2006 гг.) // Карадаг - 2009: Сборник научных трудов, посвящённых 95-летию Карадагской научной станции и 30-летию Карадагского природного заповедника Национальной академии наук Украины. Севастополь: ЭКОСИ- Гидрофизика, 2009. - С. 446-461 


\section{HYDROLOGICAL AND HYDROCHEMICAL SITUATION AND MEROPLANKTON} STATUS IN THE COASTAL WATERS OF KARADAG IN MAY AND SEPTEMBER 2017

Troshchenko O.A., Kovrigina N.P., Lisitskaya E.V., Kapranov S.V., Eremin I.Y., Rodionova N.Y.

Kovalevsky Institute of Marine Biological Research RAS, Sevastopol Russian Federation

e-mail: maricultura@mail.ru

Results of comprehensive research of coastal waters of the Karadag Nature Reserve and Koktebel' Bay carried out in May and September 2017 are presented in this study. The influence of domestic sewage of Koktebel' and Kurortnoye settlements on fields of hydrological and hydrochemical parameters and on meroplankton status at the coastal stations along four cross-sections is studied. The thermohaline fields in the two fieldworks are shown to be uniform enough. A slight increase of the horizontal gradients is observed in the area of Cape Mal'chin. From the $\mathrm{BOD}_{5}$ and oxidizabililty values exceeding maximum permissible concentrations (MPC) and the pollution factors (the ratio of $\mathrm{BOD}_{5}$ and oxidizabililty) above unity, the domestic sewage-polluted areas are detected. The content of dissolved organic carbon $\left(\mathrm{C}_{\text {ров }}\right)$ in the surface water of Karadag coastal area and Koktebel' Bay is calculated and compared with that of the initial stage of the research (in 2004). From the mineral and total phosphorus ratio values $\mathrm{P}_{\min } / \mathrm{P}_{\text {tot }}<30 \%$ and the high concentrations of silicon and mineral phosphorus, the impact of the Azov Sea water inflow on the hydrochemical structure of the water area under study is revealed. The taxonomic composition of meroplankton of Karadag coastal waters is studied. From the values of the calculated paired correlation coefficients, relations among all abiotic parameters and meroplankton content are considered. The collation of meroplankton abundance and concentration of nutrients in May at the coastal stations along the cross-sections is performed.

Key words: hydrological and hydrochemical indices, Azov Sea water, deep water inflow, meroplankton, Karadag coastal area, Black Sea 